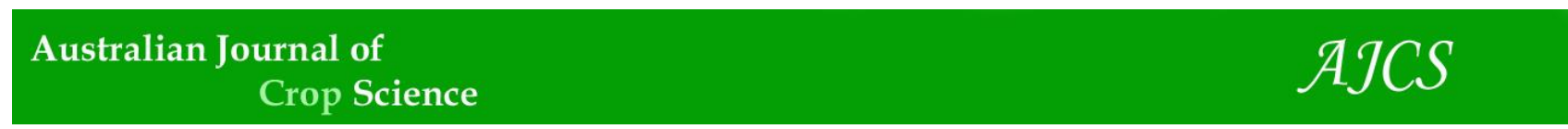

AJCS 11(11):1474-1480 (2017)

ISSN:1835-2707

doi: 10.21475/ajcs.17.11.11.pne726

\title{
Nitrogen fixation of Poaceae and Leguminoseae in a green manure experiment in the Brazilian semiarid region
}

\author{
Reginaldo Alves Ferreira Neto ${ }^{1}$, Ana Dolores Santiago de Freitas $^{2 *}$, Vanderlise Giongo ${ }^{3}$, Plínio \\ Barbosa Camargo ${ }^{4}$, Rômulo Simões Cezar Menezes ${ }^{1}$, Everardo Valadares de Sá Barretto Sampaio ${ }^{1}$
}

\author{
${ }^{1}$ Universidade Federal de Pernambuco, Av. Prof. Luís Freire, 1000, CEP 50740-540, Cidade Universitária, \\ Recife, PE, Brazil \\ ${ }^{2}$ Universidade Federal Rural de Pernambuco, Av. Dom Manoel de Medeiros, s/n, CEP 52171-900, Dois Irmãos, \\ Recife, PE, Brazil \\ ${ }^{3}$ Empresa Brasileira de Pesquisa Agropecuária, Caixa Postal 23, CEP 56302-970, Petrolina, PE, Brazil \\ ${ }^{4}$ Universidade de São Paulo - Centro de Energia Nuclear na Agricultura , Av. Centenário, 303. CEP 13416-000 \\ Piracicaba, SP, Brazil
}

*Corresponding author: anadoloressantiagodefreitas@gmail.com

\begin{abstract}
Mixtures of green manure species, including Leguminosae and Poaceae, planted prior to commercial crops may incorporate more biomass than Leguminosae alone and fix more nitrogen than Poaceae alone. Biomass and nitrogen incorporation of three plant treatmens were compared under irrigation condition. In two mixture treatments, the same seven green manure species were planted together but with different seeding proportions. Treatment (1) (low-legume) had 50\% the recommended seeding rate of the legume species (jack beans, cowpea and sunn hemp) and $150 \%$ the recommended seeding rate of the non-legume species (maize, pearl millet, sorghum and sun flower). The other treatment (2) (high-legume) had opposite proportions. In the third treatment, no green manure plants were sown and weed plants were allowed to grow. The results showed that biomass $\left(9.1\right.$ and $\left.8.2 \mathrm{Mg}^{-1}\right)$ and nitrogen accumulation (160 and $161 \mathrm{~kg} \mathrm{ha}^{-1}$ ) did not differ between the low-legume and high-legume treatments, respectively, which were 2.5 times higher than those of the weed treatment $\left(3.3 \mathrm{Mg} \mathrm{ha}^{-1}\right.$ and $\left.58.1 \mathrm{~kg} \mathrm{ha}^{-1}\right)$. Despite the higher non-legume biomass proportion and lower nitrogen concentration, the low-legume treatment symbiotically fixed as much $\mathrm{N}\left(52 \mathrm{~kg} \mathrm{ha}^{-1}\right)$ as the high-legume treatment because sorghum derived more $\mathrm{N}$ from the atmosphere (79 \%) and maize in the same range as the legume species (37 to $54 \%)$. Therefore, sorghum and maize can have high $\mathrm{N}$ endophytic fixation and green manure prior to commercial crops can be produced both with legume and Poaceae species mixed together, providing a high input of $\mathrm{N}$ and biomass in a short period.
\end{abstract}

Keywords: ${ }^{15} \mathrm{~N}$ natural abundance, cover crops, diazotrophs, grass, legumes, rhizobia.

Introduction

Green manure is a well-known practice to add organic matter (Steenwerth and Belina, 2008) and nitrogen (Zotarelli et al., 2012) to the soil before planting a commercial crop. When legume species are used as green manure, enough $\mathrm{N}$ may be incorporated from symbiotic fixation to render unnecessary nitrogen fertilization of the commercial crop (Allen et al., 2011; Zotarelli et al., 2012). However, not only legume species fix N, certain tropical Poaceae species such as maize and sugarcane can incorporate atmospheric $\mathrm{N}$ via symbiosis with endophytic bacteria (Montañez et al., 2009; Urquiaga et al., 2012). As C4 species have higher photosynthesis potential than $\mathrm{C} 3$ species, they can produce more biomass than legume species (Pedroso et al., 2014). Planting these Poaceae species as sole green manure crops is not a common practice but they have been lately tested as part of mixtures of several species planted together (Snapp et al., 2005; Miyazawa et al., 2010; Pimentel et al., 2011; Feitosa et al., 2015; Mouco et al., 2015; Pereira Filho et al., 2016). These mixtures have the potential to maximize biomass production but little is known of their capacity to fix N. Perhaps the lack of information comes from the variability of fixation in the
Poaceae, apparently high in some places (Montañez et al., 2009; Morais et al., 2012; Taulé et al., 2012; Baptista et al., 2014; Santos et al., 2017) but completely absent in other places (Biggs et al., 2002; Hoefsloot et al., 2005). If fixation of these Poaceae as sole crops is little known, even less has been studied when several species are mixed, including legume species in the mixture.

Irrigated fruit crops of high value, such as grape, mango and melon are cultivated in the sandy soils of Northeast Brazil (IBGE, 2010). Green manure may counterbalance the rapid decrease in soil organic matter brought by the high rates of organic matter decomposition, which occur under conditions of high temperature and ultraviolet radiation (Parton et al., 2007; King et al., 2012) and high soil humidity (Lee et al., 2014). In spite of green manure mixtures being a growing practice in the region (Pimentel et al., 2011; Feitosa et al., 2015; Mouco et al., 2015; Pereira Filho et al., 2016), determinations of their biomass production and especially $\mathrm{N}$ fixation are scarce. Periodical incorporation of spontaneous vegetation is also a growing and less studied practice in the region. 
Considering the growing importance of green manure in the region and the worldwide scarcity of information about fixation in Poaceae and Leguminosae mixtures, we compared biomass and nitrogen incorporation of two species mixtures, comprising of different Leguminosae and Poaceae seeding proportions, and by spontaneous vegetation, under irrigated conditions in Northeast Brazil. We hypothesized that: (1) the species mixtures would produce more than the spontaneous plants; (2) the mixture planted with more non-leguminous species seeds would produce more biomass but with lower $\mathrm{N}$ concentration than the mixture with more leguminous species seeds; and (3) $\mathrm{N}$ concentrations and $\mathrm{N}$ symbiotic fixation would be higher in the Leguminosae species than in the Poaceae species.

\section{Results}

\section{Biomass}

The two planted treatments with high and low-legume mixtures produced similar total aboveground biomasses, both twice and half as much as the spontaneous plant treatment (Table 1). In low-legume mixture, the aggregate biomass of the non-legume species was significantly higher than the biomass of the legume species. In the high-legume mixture, the biomasses of the non-legume species was also slightly higher than the biomass of the legume species but the difference was not statistically significant.

In the low-legume mixture, the highest biomass was produced by sunflower and maize and lower biomass of millet, sorghum and all legume species (Fig. 1). In the highlegume treatments, sunn hemp and jack beans produced as much as sunflower, maize and sorghum. Cowpea and millet had low productions in both treatments.

\section{Nitrogen concentration and accumulation}

The total amounts of nitrogen accumulated in the biomass were also similar in two planted treatments and almost three times higher than the $\mathrm{N}$ accumulated in the biomass of the spontaneous plant treatment (Table 1). The similarity of $\mathrm{N}$ accumulation in two planted treatments was occurred in spite of the higher $\mathrm{N}$ concentration in the legume biomass with consequently lower $\mathrm{C}: \mathrm{N}$ ratio (Table 1), which was compensated by the differences in biomass production. The $\mathrm{N}$ concentration in the spontaneous plants was only slightly higher than those of the non-legume species. Nitrogen concentrations of each of the planted species were similar in two planted treatments (Table 2). The higher concentrations of all legume species ( 25.2 to $32.0 \mathrm{~g} \mathrm{~kg}^{-1}$ ) than those of nonlegume species (12.0 to $16.7 \mathrm{~g} \mathrm{~kg}^{-1}$ ) resulted in higher proportions of the accumulated $\mathrm{N}$ in the legume species than the relative proportions of their biomasses.

\section{Nitrogen fixation}

The $\delta^{15} \mathrm{~N}$ signals of all planted Poacae and Leguminosae were significantly lower than the $\delta^{15} \mathrm{~N}$ signal of sunflower, assumed as reference species, except for millet and jack beans (Table 2). The $\delta^{15} \mathrm{~N}$ signal of the spontaneous plants was similar to that of sunflower and the $\delta^{13} \mathrm{C}$ abundance was only slightly lower than those of the planted Poaceae (Table 2 ), reflecting the observed predominance of non-fixing grass species growing in the plots of this treatment. The $\delta^{13} \mathrm{C}$ signals of the planted species were lower for the $\mathrm{C} 3$ species (all legume species and sunflower) and higher for the $\mathrm{C} 4$ Poaceae species. The proportions of atmospheric $\mathrm{N}$ in the plants, obtained from symbiosis, excluding millet and jack beans from the calculation, varied from $37 \%$ in sunn hemp to $79 \%$ in sorghum (Table 2). These proportions in relation to the amounts of $\mathrm{N}$ in each species translated into 5 to $22 \mathrm{~kg} \mathrm{~N}$ fixed (Fig 2) and the sums for all species were similar in the two planted treatments, amounting to more than $52 \mathrm{~kg} \mathrm{~N} \mathrm{ha}^{-1}$ (Table 1).

\section{Discussion}

Both planted treatments produced high amounts of biomass (Table 1), considering the short cycle of production (> 8 ton $\mathrm{ha}^{-1}$ in 75 days). This high production can be explained by the adequate temperature and ample nutrient, light and water supply but also by the rapid development of a light absorbing leaf cover provided by the competition of species in the mixtures of seeds. The cover of the spontaneous species developed much slower because their plant density depended on the soil seed bank, probably depleted by weeding procedures of previous crops, and on the eventual dispersal of seeds from neighboring fields. Therefore, to maximize the amount of biomass to be incorporated, it is recommended to plant mixtures of green manure species and not only leave the weed plants to grow.

The aggregate biomass of the Poaceae was higher than that of the Leguminosae, even in the high-legume treatment, despite the lower proportion of non-legume seeds that were sown in this treatment (Table 1). Among the Poaceae, maize and sorghum outcompeted millet, a crop that usually produces less biomass than the other two and that is especially recommended under conditions of water limitation (Muchow 1989). Under the irrigated conditions of green manure production in Northeast Brazil, millet could be excluded from the mixtures. The higher growth of the Poaceae could be attributed to their more efficient C4 photosynthetic pathway. Sunflower which is a C3 species with lower photosynthetic efficiency had high biomass production in both planted treatments. Certainly, competition envolves more than photosynthetic pathway and plant architecture could be one of the important factors. Sunflower, maize and sorghum plants have higher initial vertical growth than the legumes, an important feature in a densely sown field which can be advantageous in light capturing. Among the legumes, cowpea produced less than sunn hemp and jack beans, these last two being usually planted as green manure, while cowpea is usually planted to produce grain. If cowpea is to be maintained in the mixture, local varieties with higher straw production (Freitas et al., 2012) should be planted.

Two advantages are traditionally attributed to legumes as green manure species: (1) the high $\mathrm{N}$ concentrations in the biomass, which facilitates decomposition and speeds up $\mathrm{N}$ liberation to the crops subsequent to the incorporation of the green manure (Perin et al., 2006); and (2) their capacity to form symbiosis with diazothrophic bacteria and to fix atmospheric nitrogen (Wagger et al., 1998; Snapp et al., 2005; Ojien et al., 2014; Ramírez-García et al., 2015; Rühlemann and Schmidtke, 2015). In fact, N concentrations were twice as high in the legume than in the non-legume species and their C:N ratios varied from 11 to 16 (Table 2). This range is considered to lead immediate $\mathrm{N}$ mineralization (Steinmaier and Ngoliya, 2001; Matos et al., 2011), opposed to the ratios of the non-legumes, which varied from 25 to 42 . This current range may lead to an initial immobilization of 
Table 1. Biomass production, $\mathrm{N}$ concentration and content, $\mathrm{C}: \mathrm{N}$ ratio and amount of $\mathrm{N}$ symbioticaly fixed from the atmosphere by legume and non-legume species in two green manure mixtures, one planted with more legume seeds (high-legume mixture) and the other with more non-legume seeds (low-legume mixture), and in plots in which spontaneous plants were left to grow in an irrigated field in Northeast Brazil.

\begin{tabular}{|c|c|c|c|c|c|}
\hline Treaments & Biomass $\left(\mathrm{kg} \mathrm{ha}^{-1}\right)$ & $\mathrm{N}$ concentration $\left(\mathrm{g} \mathrm{kg}^{-1}\right)$ & $\mathrm{C}: \mathrm{N}$ & $\mathrm{N}$ accumulation $\left(\mathrm{kg} \mathrm{ha}^{-1}\right)$ & Fixed N(kg ha $\left.{ }^{-1}\right)$ \\
\hline \multicolumn{6}{|l|}{ Low-legume mixture } \\
\hline Legumes & 3577 aA & $28.2 \mathrm{aA}$ & 14.1bA & $98.0 \mathrm{aA}$ & $26.0 \mathrm{aA}$ \\
\hline Non-legumes & $4578 \mathrm{aB}$ & $14.8 \mathrm{bA}$ & $27.2 \mathrm{aA}$ & $62.5 \mathrm{aA}$ & $26.5 \mathrm{aA}$ \\
\hline Total & $8155 \alpha$ & $20.6 \alpha$ & $19.4 \beta$ & $160.5 \alpha$ & $52.5 \alpha$ \\
\hline \multicolumn{6}{|l|}{ High-legume mixture } \\
\hline Legumes & $2504 \mathrm{bA}$ & $26.3 \mathrm{aA}$ & $15.0 \mathrm{bA}$ & $66.4 \mathrm{aA}$ & $21.1 \mathrm{aA}$ \\
\hline Non-legumes & $6574 \mathrm{aA}$ & $15.3 \mathrm{bA}$ & $25.7 \mathrm{aA}$ & $93.5 \mathrm{aA}$ & $31.5 \mathrm{aA}$ \\
\hline Total & $9078 \alpha$ & $18.0 \beta$ & $21.9 \beta$ & $159.9 \alpha$ & $52.6 \alpha$ \\
\hline Spontaneous plants & $3340 \beta$ & $17.4 \mathrm{~B}$ & $27.60 \alpha$ & $58.05 \beta$ & $0 \beta$ \\
\hline
\end{tabular}

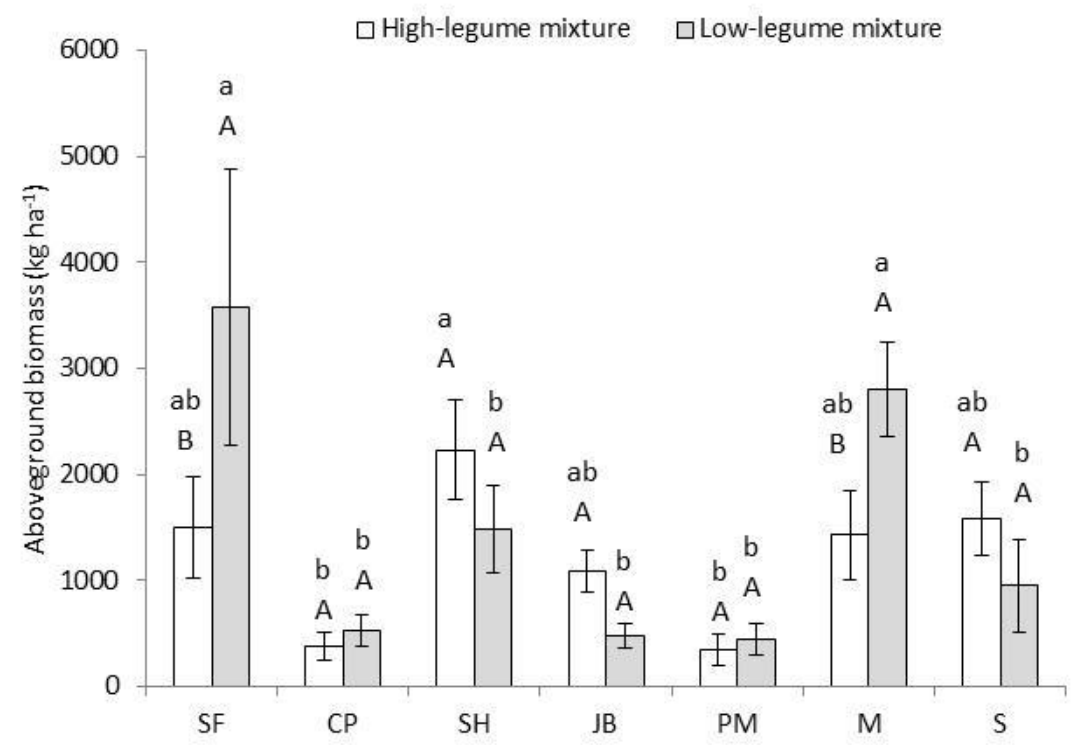

Fig 1. Biomass yield of species cultivated as green manure mixtures planted with more legume seeds (high-legume mixture) or with more non-legume seeds (low-legume mixture) in an irrigated field in Northeast Brazil. SF $=$ sunflower, $\mathrm{CP}=\mathrm{cowpea}, \mathrm{SH}=\mathrm{sunn}$ hemp, $\mathrm{JB}=$ jack beans, $\mathrm{PM}=$ pearl millet, $\mathrm{M}=$ maize, $\mathrm{S}=$ sorghum. Bars with the same letter are not significantly different by the Tukey test at the 0.05 probability level, small letters comparing species within each mixture and capital letters comparing the two mixture for each species. Vertical lines in the bars are mean standard deviation.

Table 2. $\mathrm{N}$ concentration $\left(\mathrm{g} \mathrm{kg}^{-1}\right), \mathrm{C}: \mathrm{N}$ ratio, ${ }^{13} \mathrm{C}$ and ${ }^{15} \mathrm{~N}$ signals $(\delta \%$ ) and proportion of $\mathrm{N}$ derived from the atmosphere (Ndfa) of species cultivated as green manure mixtures and spontaneous plants left to grow in an irrigated field in Northeast Brazil.

\begin{tabular}{|c|c|c|c|c|c|}
\hline Species & $\mathrm{N}(\%)$ & C:N & $\delta^{13} \mathrm{C}(\%)$ & $\delta^{15} \mathrm{~N}(\%)$ & Ndfa (\%) \\
\hline \multicolumn{6}{|l|}{ Cultivated Species } \\
\hline Sunflower & $1.67 \mathrm{~b}$ & $25.32 \mathrm{~b}$ & $-29.26 b$ & 4.56 & - \\
\hline Cowpea & $3.04 \mathrm{a}$ & $16.49 \mathrm{a}$ & $-28.73 b$ & $1.73 *$ & 46 \\
\hline Sunn hemp & $2.57 \mathrm{a}$ & $16.76 \mathrm{a}$ & $-28.85 b$ & $2.47 *$ & 37 \\
\hline Jack beans & $3.20 \mathrm{a}$ & $11.84 \mathrm{a}$ & $-28.56 b$ & $2.73 \mathrm{~ns}$ & - \\
\hline Millet & $1.64 \mathrm{~b}$ & $26.18 \mathrm{~b}$ & $-13.10 \mathrm{a}$ & $3.10 \mathrm{~ns}$ & - \\
\hline Maize & $1.48 \mathrm{~b}$ & $32.67 \mathrm{~b}$ & $-13.89 a$ & $2.08 *$ & 54 \\
\hline Sorghum & $1.17 \mathrm{~b}$ & $41.22 \mathrm{c}$ & $-12.12 \mathrm{a}$ & $0.95 *$ & 79 \\
\hline Spontaneous plants & 1.74 & 27.60 & -15.35 & 4.88 & - \\
\hline
\end{tabular}



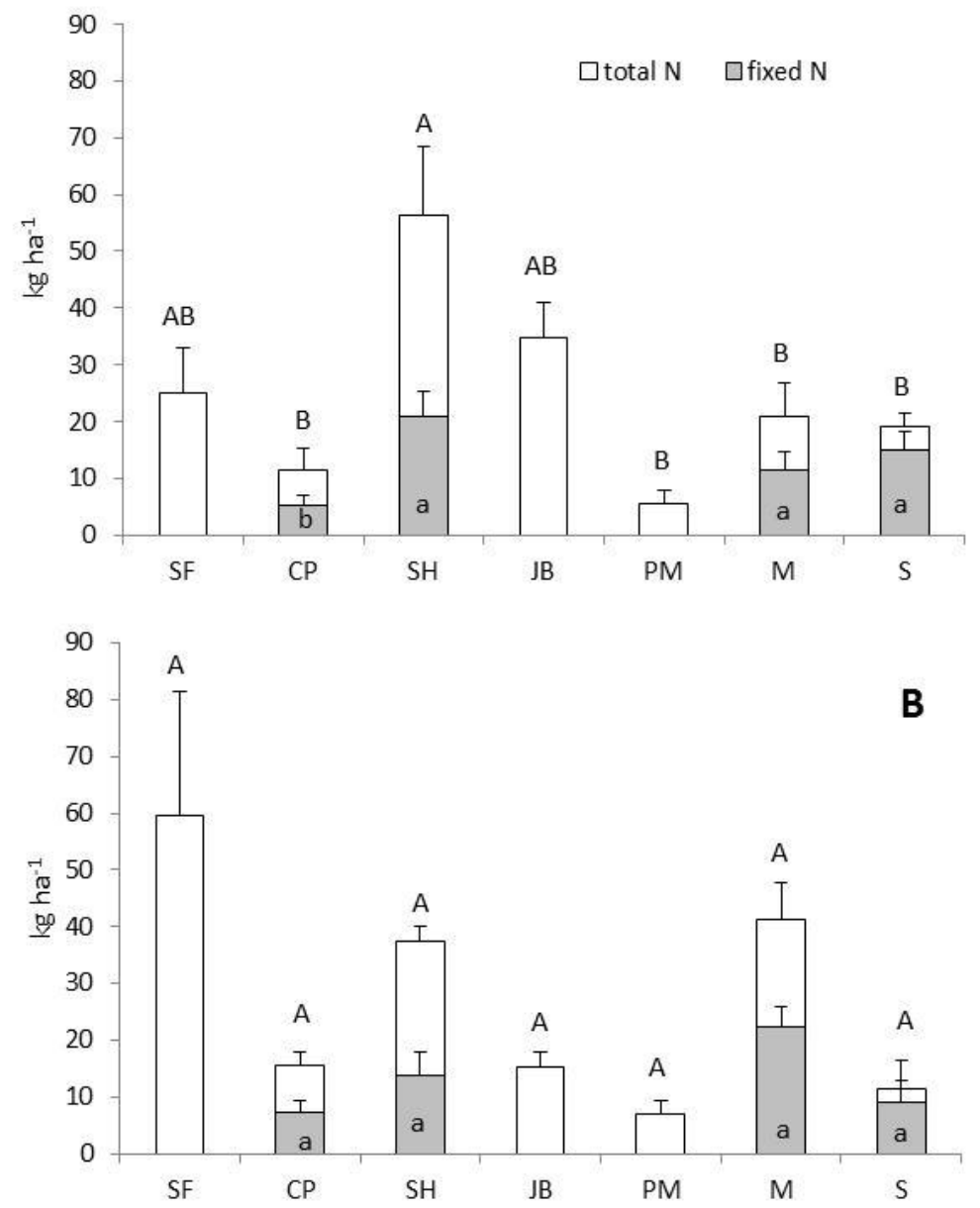

Fig 2. Nitrogen yield and nitrogen fixation of species cultivated as green manure mixtures planted with more legume seeds (highlegume mixture, (A) or with more non-legume seeds (low-legume mixture, (B) in an irrigated field in Northeast $\mathrm{Brazil}$. $\mathrm{SF}=$ sunflower, $\mathrm{CP}=$ cowpea, $\mathrm{SH}=$ sunn hemp, $\mathrm{JB}=$ jack beans, $\mathrm{PM}=$ millet, $\mathrm{M}=$ maize, $\mathrm{S}=$ sorghum. Bars with the same letter are not significantly different by the Tukey test at the 0.05 probability level, small letters comparing fixed nitrogen and capital letters comparing nitrogen yield for each species within each mixture. Vertical lines in the bars are mean standard deviation.

soil $\mathrm{N}$, temporarily reducing the supply to the subsequent crops (Wagger et al., 1998; Perin et al., 2006).

Two of the legume species, cowpea and sunn hemp, fixed about half of their $\mathrm{N}$ through symbiosis without artificial inoculation, confirming the potential of legume species to add nitrogen to crop systems, when used as green manure. Reports of fixation by these species are common in the literature, frequently reaching even higher proportions of their N (Ojien et al., 2007; Freitas et al., 2012). Specially important was the fixation in sunn hemp, the legume species which produced the most biomass and contributed with $40 \%$ of the fixed $\mathrm{N}$ in the high-legume mixture treatments. Contrary to the expectation, jack beans had a $\delta^{15} \mathrm{~N}$ signal only slightly lower and not significantly different from the $\delta^{15} \mathrm{~N}$ signal of sunflower, preventing a reliable calculation of its fixation. This specie is recognized as a potentially fixer (Ojien et al., 2007). The cause of the low or absent fixation in both planted treatments is not known, particularly considering that the other two legume species formed efficient symbiosis. It is unlikely that a climatic or edaphic factor is impeding fixation which could be caused by absence of a specific bacteria to form symbiosis. Inoculation with previously selected, high fixing, compatible bacteria species could correct the problem (Marinho et al., 2014) but this is not a common practice in the country or in other areas, where jack beans is planted as a green manure species (Ojien et al.,
2007). Confirming that fixation can occur in Poaceae species (Miranda et al., 1990; Montañez et al., 2009; Morais et al., 2012; Urquiaga et al., 2012; Santos et al., 2017), maize and sorghum had low $\delta 15 \mathrm{~N}$ signal and in the case of sorghum even lower than the signals of all legume species. Proportions of Poaceae plant $\mathrm{N}$ derived from fixation vary much depending on the species and environmental conditions and are usually inferior to those of legume species (Alves et al., 2015; Santos et al., 2017). The lower $\delta^{15} \mathrm{~N}$ signal of sorghum is an important issue because it rules out the possibility that the atmospheric $\mathrm{N}$ present in these sorghum plants was transferred by the legume species (Peoples et al., 2015). The higher $\delta^{15} \mathrm{~N}$ signal of sunflower plants, in both high- and lowlegume treatments and the similarity of this signal with that of the spontaneous plants reinforces the idea that transference from legume to non-legume species was not occurring or occurring at low rates. Considering the fact that sunflower was chosen as the reference species would result in an underestimation of fixation in the other species. The very low $\delta^{15} \mathrm{~N}$ signal of sorghum also decreases the effect of a possible error in the calculation due to the uncertainty in the $\mathrm{B}$ value of Poaceae, currently adopted as zero (Morais et al., 2012; Baptista et al., 2014). In contrast, the values in legume species vary from $-1.61 \%$ to $-1.00 \%$ (Unkovich et al., 2008; Ojiem et al., 2007). Fixation in the sorghum plants was $79 \%$ of their $\mathrm{N}$ and if a $\mathrm{B}$ value similar to those of the 
legume species was adopted (say $-1.0 \%$ ), fixation would decrease only to $65 \%$ of the plant N. This is a proportion higher than already reported for this species (Stein et al., 1997; Santos et al., 2017) and shows that the Poaceae fixation can be as efficient

as that of legumes. On the other hand, the $\delta^{15} \mathrm{~N}$ signal of millet was not significantly different from that of sunflower, indicating absence of fixation, as occurred in jack beans.

Since maize and sorghum contributed high proportion amounts of $\mathrm{N}$ in the biomass of both planted treatments and as their proportions of fixation were high, they represented about two thirds of the fixed $\mathrm{N}$ in the low-legume mixture and about half in the high-legume mixture treatment (Table 1). Therefore, contrary to our hypothesis, not only the lowlegume mixture treatment fixed as much $\mathrm{N}$ as the highlegume treatment but also this fixation was not predominantly due to the presence of legume species in both treatments. This results contradicts with the established concept that legumes are preferred as green manure species because of their $\mathrm{N}$ fixation. Poaceae species can fix as much as the legumes and produce higher biomass amounts.

However, extrapolation of this result to other areas needs confirmation of the establishment of effective symbiosis between Poaceae species and diazotrophic bacteria in each site. Several nitrogen-fixing species, especially of Azospirillum, Herbaspirillum, Gluconacetobacter and Burkholderia genera can colonize the surface or the inner roots of sorghum (Coelho et al., 2009; Luna et al., 2010; Yoon et al., 2016), maize (Roncato-Maccari et al., 2003; Roesch et al., 2006; Montañez et al., 2009) and elephant grass (Videira et al., 2014) among other tropical grasses. But it remains unclear to what extent the plants benefit from $\mathrm{N}$ fixed by endophytic diazotrophs or from the production of indole-3-acetic acid (IAA) or other growth-promoting substances that are proven to cause morphological changes in roots (such as increased lateral roots and root hairs); thus, increasing nutrient absorption (Beneduzi et al., 2013; Videira et al., 2014; Alves et al., 2015). The current knowledge on the subject indicates that species such as sugarcane can fix high proportions of $\mathrm{N}$ in some places, particularly in Brazil (Urquiaga et al., 2012; Baptista et al., 2014), and have no fixation in other countries, like Australia (Biggs et al., 2002) and South Africa (Hoefsloot et al., 2005). Reports for maize fixation are less numerous than for sugarcane but rather divergent results (Montañez et al., 2009; Alves et al., 2015). Fixation in sorghum has been reported by some authors (Stein et al., 1997; Santos et al. 2017) but our data are the first employing the ${ }^{15} \mathrm{~N}$ abundance technique showing high estimates of biological nitrogen fixation.

\section{Materials and Methods}

\section{Esperimental site}

A field experiment was conducted in Mandacaru Experimental Station (09 24' S; 40 $26^{\circ}$ O; 375.5 m) under irrigated conditions in the Brazilian semiarid region (Juazeiro municipality, Bahia state). The average annual rainfall is 542 $\mathrm{mm}$, concentrated from January to April, and the soil is a HaplicVertisol, with the following characteristics in the 0 to $20 \mathrm{~cm}$ superficial layer (analyzed following the procedures recommended by EMBRAPA, 1997): sand, silt and clay = 392,167 and $441 \mathrm{~g} \mathrm{~kg}^{-1}$, respectively; $\mathrm{pH}$ (water $\left.1: 2.5\right)=$ 7.4; organic matter $=7.76 \mathrm{~g} \mathrm{~kg}^{-1}$; extractable $\mathrm{P}($ Mehlich $\mathrm{I})=$ $199 \mathrm{mg} \mathrm{kg}^{-1}$; and $\mathrm{K}^{+}, \mathrm{Ca}^{2+}, \mathrm{Mg}^{2+}, \mathrm{Na}^{+} \mathrm{e} \mathrm{Al}^{3+}=0.62$, 22.6, $3.0,0.21$ and $0 \mathrm{cmol}_{\mathrm{c}} \mathrm{dm}^{-3}$, respectively.

\section{Experimental desing}

The experiment was set up in a randomized block design, with six replications and three treatments, corresponding to two mixtures of planted green manure species and one treatment in which no species was seeded and spontaneous plant species (weeds) were left to grow. In both planted treatments, seven species were planted together in each plot: jack beans (Canavalia ensiformis L. DC), cowpea (Vigna unguiculata L. Walp), sunn hemp (Crotalaria spectabilis Roth), maize (Zea mays L.), pearl millet (Pennisetum glaucum L.), sorghum (Sorghum bicolor (L.) Moench.) and sun flower (Helianthus annuus L.). The two planted treatments differed in the proportions of seeds sown in the plots. The first treatment, designated as low-legume mixture, was planted with $50 \%$ of the recommended seeding rate for the three legume species and $150 \%$ of the recommended seeding rate for each non-legume species. The second treament, designated as high legume mixture, was planted with $150 \%$ of the recommended seeding rate for the three legume species and $50 \%$ of the other species. The third treatment, in which the spontaneous plants were left to grow, is henceforth designated as spontaneous plant treatment.

The seeds were planted in 12 lines per plot of $6 \mathrm{~m} \times 8 \mathrm{~m}$, each line separated $0.5 \mathrm{~m}$ to the next. The plots were drip irrigated with water ducts $1 \mathrm{~m}$ apart and drippers every $0.5 \mathrm{~m}$. Water was applied thrice a week in volumes calculated based on evaporation from a class A tank. The aboveground biomass of all plants was harvested 75 days after seeding, when most of the species were flowering. Sampling was done placing a $1 \mathrm{~m} \times 1 \mathrm{~m}$ quadrat in each plot, collecting all the biomass and separating the plants of each species of the mixtures. In the spontaneous plant treatment, the plants were not separated by species.

\section{Plant analysis}

The plant samples were dried, weighted and ground to fine powder. A sub-sample was placed in a capsule and loaded into a ThermoQuest-Finnigan Delta Plus isotope ratio mass spectrometer (Finnigan-MAT; CA, USA) interfaced with an Elemental Analyzer (Carlo Erba model 1110; Milan, Italy) at the Laboratory of Isotope Ecology (CENA-USP, Brazil) to obtain the carbon and nitrogen isotope ratio and the total carbon and nitrogen concentrations. Stable isotope ratios of nitrogen were measured relative to internationally recognized standards. The concentrations of ${ }^{15} \mathrm{~N}$ and ${ }^{13} \mathrm{C}$ were expressed in $\delta$ units in relation to the international standard, based on the equation $\delta=\left(\mathrm{R}_{\text {sample }} / \mathrm{R}_{\text {standard }}-1\right) \times 1000$, where $\mathrm{R}_{\text {sample }}$ and $\mathrm{R}_{\text {standard }}$ are the ratios ${ }^{15} \mathrm{~N}:{ }^{14} \mathrm{~N}$ and ${ }^{13} \mathrm{C}:{ }^{12} \mathrm{C}$ of the material and the standards (atmospheric $\mathrm{N}_{2}$ for $\mathrm{N}$ and Pee Dee Belemnite for C).

When the difference in the average $\delta^{15} \mathrm{~N}$ signal of potentially fixing species (both Leguminosae and Poaceae) in relation to the $\delta^{15} \mathrm{~N}$ signal of sunflower (considered as a reference species) was larger than 2 units (Högberg, 1997) and significantly different $(\mathrm{p} \leq 0,05)$, we calculated the proportion of $\mathrm{N}$ derived from the atmosphere (\%Ndfa), using the equation (Shearer and Kohl 1986): \%Ndfa = $\left[\left(\delta^{15} \mathrm{~N}_{\text {(reference) }}-\delta^{15} \mathrm{~N}_{\text {(fixing) }}\right) / \delta^{15} \mathrm{~N}_{\text {(reference) }}-\mathrm{B}\right] \times 100$, where $\left(\delta^{15} \mathrm{~N}_{\text {(reference) }}\right.$ is the average $\delta^{15} \mathrm{~N}$ value of sunflower and $\delta^{15} \mathrm{~N}_{\text {(fixing) }}$ is the $\delta^{15} \mathrm{~N}$ value of each potentially fixing species. The $\mathrm{B}$ values, which are the $\delta^{15} \mathrm{~N}$ values of the potentially fixing species in the absence of $\mathrm{N}$ supply except atmospheric $\mathrm{N}$, were based on reported values: $-1.61 \%$ for cowpea and $1.08 \%$ for sunn hemp (Unkovich et al., 2008); $-1.00 \%$ for jack beans (Ojiem et al. 2007); and $0 \%$ for the Poaceae 
(Morais et al., 2012). The amount of fixed $\mathrm{N}$ was calculated multiplying the proportion of $\mathrm{N}$ derived from the atmosphere (\% Ndfa) by the $\mathrm{N}$ content of each species, obtained multiplying the $\mathrm{N}$ concentration in the sample material by the total aboveground biomass of the species in the plot.

\section{Data analysis}

Data on total biomass, $\mathrm{N}$ concentrations and contents, C:N ratio, and amount of fixed $\mathrm{N}$ were subjected to analysis of variance following a randomized block design, with six replications and three treatments. Since the species were collected separately within each of the planted treatments, data on all the above variables were also analyzed following a sub-divided plot design, where the plots corresponded to the two high- and low-legume mixtures and two sub-plots corresponded to the two groups of all legumes and all nonlegumes. Similar analysis were made for data on biomass, $\mathrm{N}$ concentrations and contents, $\mathrm{C}: \mathrm{N}$ ratio, $\delta^{15} \mathrm{~N}$ and $\delta^{13} \mathrm{C}$ in which the two plots corresponded to the two mixture treatments and seven subplots corresponded to the seven species. Another analysis was made for data on amount of fixed $\mathrm{N}$, in which the plots corresponded to the two mixture treatments and six subplots corresponded to the six potentially fixing species (excluding sunflower). To estimate fxation, the $\delta^{15} \mathrm{~N}$ value of each potentialy fixing species was compared to the $\delta^{15} \mathrm{~N}$ value of sunflower using a t-test. Proportion data were submitted to arcsine transformation before analysis. The averages were compared by the Tukey test at the 0.05 probability level.

\section{Conclusion}

Two treatments planted with different legume seeding rates (high- and low-legume mixtures) produced similar total aboveground biomasses ( 8 and $9 \mathrm{Mg} \mathrm{ha}^{-1}$ ) and accumulated similar $\mathrm{N}$ amounts $\left(160 \mathrm{Mg} \mathrm{ha}^{-1}\right)$, both 2.5 more than the unplanted treatment, in which weeds were left to grow. Therefore, to maximize the amount of biomass to be incorporated as green manure we recommend cultivation of plant mixtures of green manure species and and not only leave the weed plants to grow. The aggregate biomass of the Poaceae was higher than that of the Leguminosae and maize and sorghum outcompeted millet, which could be excluded from the seed mixtures of both green manure planted tratments. Both planted treatments fixed more than $52 \mathrm{~kg} \mathrm{~N}$ $\mathrm{ha}^{-1}$ from the atmosphere and the Poaceae contributed with high proportions (>50\%) of this fixation. Fixation was especially high in sorghum (79 \% of its $\mathrm{N}$ ). In maize, it was in the same range as the fixation in the legume species (37 to $54 \%$ ). Therefore, Poaceae with high $\mathrm{N}$ endophytic fixation may be included in seed mixtures of different species sown as green manure to incorporate biomass and nitrogen to the fields to be subsequently planted with irrigated cash crops.

\section{Aknowledgments}

The authors thank Conselho Nacional de Desenvolvimento Científico e Tecnológico (CNPq; Projeto Universal 2012, grant number 472997/2012-2); Fundação de Amparo à Ciência e Tecnologia de Pernambuco (FACEPE; grant number APQ-0199-5.01/15) and Empresa Brasileira de Pesquisa Agropecuária (EMBRAPA; Rede de pesquisa para avaliação do impacto ambiental de sistemas de produção de melão sobre as mudanças climáticas/Repensa-Melão, Edital $22 / 2010$ ) for the financial support.

\section{References}

Allen BL, Pikul JL, Waddell JT, Cochrand VL (2011) Longterm lentil green-manure replacement for fallow in the Semiarid Northern Great Plains. Agron J. 103:1292-1298.

Alves GC, Videira SS, Urquiaga S, Reis VM (2015) Differential plant growth promotion and nitrogen fixation in two genotypes of maize by several Herbaspirillum inoculants. Plant Soil. 387:307-321.

Baptista RB, Morais RF, Leite JM, Schultz N, Alves BJR, Boddey RM, Urquiaga $S$ (2014) Variations in the ${ }^{15} \mathrm{~N}$ natural abundance of plant-available $\mathrm{N}$ with soil depth: their influence on estimates of contributions of biological $\mathrm{N}_{2}$ fixation to sugar cane. Appl Soil Ecol. 73:124-129.

Beneduzi A, Moreira F, Costa PB, Vargas LK, Lisboa BB, Favreto R, Baldani JI, Passaglia LMP (2013) Diversity and plant growth promoting evaluation abilities of bacteria isolated from sugarcane cultivated in the South of Brazil. Appl Soil Ecol. 63:94-104.

Biggs IM, Stewart GR, Wilson JR, Critchley C (2002) N natural abundance studies in Australian commercial sugarcane. Plant Soil. 238:21-30.

Coelho MRR, Marriel IE, Jenkins SN, Lanyon CV, Seldin L, O'Donnell AG (2009) Molecular detection and quantification of nifH gene sequences in the rhizosphere of sorghum (Sorghum bicolor) sown with two levels of nitrogen fertilizer. Appl Soil Ecol. 42:48-53.

Embrapa - Empresa Brasileira de Pesquisa Agropecuária (1997) Manual de métodos de análise de solo (2 ed), Rio de Janeiro, 1997.

Feitosa JR, Mendes MAS, Olszevski N, Cunha TJF, Cortez JW, Giongo V (2015) Physical attributes of ultisol of Brazil's northeastern semiarid under organic farming of wine grapes. An Acad Bras Cienc. 87:483-493.

Freitas ADS, Sampaio EVSB, Silva AF (2012) Yield and biological nitrogen fixation of cowpea varieties in the semiarid region of Brazil. Biomass Bioenerg. 45:109-114.

Hoefsloot G, Termorshuizen AJ, Watt DA, Cramer MD (2005) Biological nitrogen fixation is not a major contributor to the nitrogen demand of a commercially grown South African sugarcane cultivar. Plant Soil. 277:85-96.

Högberg P (1997) ${ }^{15} \mathrm{~N}$ natural abundance in soil-plant systems. New Phytol. 137:179-203.

IBGE - Instituto Brasileiro de Geografia e Estatística (2010). Produção Agrícola Municipal, Rio de Janeiro, 2010.

King JY, Brandt LA, Adair EC (2012) Shedding light on plant litter decomposition: advances, implications and new directions in understanding the role of photodegradation. Biogeochemistry. 111:57-81.

Lee H, Fitzgerald J, Hewins DB, McCulley RL, Archer SR, Rahn T, Throop HL (2014) Soil moisture and soil-litter mixing effects on surface litter decomposition: a controlled environment assessment. Soil Biol Biochem. 72:123-132.

Luna MF, Galar ML, Aprea J, Molinari ML, Boiardi JL (2010) Colonization of sorghum and wheat by seed inoculation with Gluconacetobacter diazotrophicus. Biotechnol Lett. 32:1071-1076.

Marinho RCN, Nóbrega RSA, Zilli JE, Xavier GR, Santos CAF, Aidar ST, Martins LMV, Fernandes Jr PI (2014) Field performance of new cowpea cultivars inoculated with efficient nitrogen-fixing rhizobial strains in the Brazilian Semiarid. Pesq Agropec Bras. 49:395-402.

Matos ES, Mendonça ES, Cardoso IM, Lima PC, Freese D (2011) Decomposition and nutrient release of leguminous plants in coffee agroforestry systems Rev Bras Cienc Solo. $35: 141-149$. 
Miranda CHB, Urquiaga S, Boddey RM (1990) Selection of ecotypes of Panicum maximum for associated biological nitrogen fixation using the ${ }^{15} \mathrm{~N}$ isotope dilution technique. Soil Biol Biochem. 22:657-663.

Miyazawa K., Murakami T, Takeda M, Murayama T (2010) Intercropping green manure crops effects on rooting patterns. Plant Soil. 331:231-239.

Montañez A, Abreu C, Gill PR, Hardarson G, Sicardi M (2009) Biological nitrogen fixation in maize (Zea mays L.) by ${ }^{15} \mathrm{~N}$ isotope-dilution and identification of associated culturable diazotrophs. Biol Fertil Soils. 45:253-263.

Morais RF, Quesada DM, Reis VM, Urquiaga S, Alves BJR, Boddey RM (2012) Contribution of biological nitrogen fixation to Elephant grass (Pennisetum purpureum Schum.). Plant Soil. 349:1-12.

Mouco MAC, Silva DJ, Giongo V, Mendes AMS (2015) Green Manures in 'Kent' Mango Orchard. Acta Hort. 1075:179-184.

Muchow RC (1989) Comparative productivity of maize, sorghum and pearl millet in a semi-arid tropical environment II. Effect of water deficits. Field Crop Res. 20:207-219.

Ojiem JO, Vanlauwe B, Ridder N, Giller KE (2007) Nichebased assessment of contributions of legumes to the nitrogen economy of Western Kenya smallholder farms. Plant Soil. 292:119-135.

Ojiem JO, Franke AC, Vanlauwe B, Ridder N, Giller KE (2014) Benefits of legume-maize rotations: Assessing the impact of diversity on the productivity of smallholders in Western Kenya. Field Crop Res. 168:75-85.

Parton W, Silver WL, Burke IC, Grassens L, Harmon ME, Curre WS, King JY, Adair EC, Brandt LA., Hart SC, Fasth B (2007) Global scale similarities in nitrogen release patterns during long-term decomposition. Science. 135:361-364.

Pedroso GM, Hutmacher RB, Putnam D, Six J, van Kessel C, Linquist BA (2014) Biomass yield and nitrogen use of potential C4 and C3 dedicated energy crops in a Mediterranean climate. Field Crop Res. 161:149-157.

Peoples MB, Chalk PM, Unkovich MJ, Boddey RM (2015) Can differences in ${ }^{15} \mathrm{~N}$ natural abundance be used to quantify the transfer of nitrogen from legumes to neighbouring non-legume plant species? Soil Biol Biochem. 87:97-109.

Pereira Filho A, Teixeira Filho J, Giongo V, Simoes WL, Lal R (2016) Nutrients dynamics in soil solution at the outset of no-till implementation with the use of plant cocktails in Brazilian semi-arid. Afr J Agric Res. 11:234-246.

Perin A, Santos RHS, Urquiaga SS, Cecon PR, Guerra JGM, Freitas GB (2006) Sunnhemp and millet as green manure for tropical maize production. Sci Agric. 63:453-459.

Pimentel MS, Carvalho RS, Martins LMV, Silva AVL (2011) Seasonal response of edaphic bioindicators using green manure in Brazilian semi-arid conditions. Rev Ciênc Agron. 42:829-836.

Ramírez-García J, Carrillo JM, Ruiz M, Alonso-Ayuso M, Quemada M (2015) Multicriteria decision analysis applied to cover crop species and cultivars selection. Field Crop Res. 175:106-115.

Roesch LFW, Olivares FL, Passaglia LMP, Selbach PA, Sá ELS, Camargo FAO (2006) Characterization of diazotrophic bacteria associated with maize: Effect of plant genotype, ontogeny and nitrogen-supply. World J Microb Biot. 22:967-974.

Roncato-Maccari LDB, Ramos HJO, Pedrosa FO, Alquini Y, Chubatsu LS, Yates MG, Rigo LU, Steffens MBR, Souza
EM (2003) Endophytic Herbaspirillum seropedicae expresses nif genes in gramineous plants. FEMS Microbiol Ecol. 45:39-47.

Rühlemann L, Schmidtke K (2015) Evaluation of monocropped and intercropped grain legumes for cover cropping in no-tillage and reduced tillage organic agriculture. Eur J Agron. 65:83-94.

Santos CLR, Alves GC, Macedo AVM, Giori FG, Pereira W, Urquiaga S, Reis VM (2017) Contribution of a mixed inoculant containing strains of Burkholderia spp. and Herbaspirillum ssp. to the growth of three sorghum genotypes under increased nitrogen fertilization levels. Appl Soil Ecol. 113:96-106.

Shearer G, Kohl DH (1986) $\mathrm{N}_{2}$ fixation in field settings: estimations based on natural ${ }^{15} \mathrm{~N}$ abundance. Aust J Plant Physiol. 13:699-756.

Snapp SS, Swinton SM, Labarta R, Mutch D, Black JR, Leep R, Nyiraneza J, O'Neil K (2005) Evaluating cover crops for benefits, costs and performance within cropping system niches. Agron J. 97:322-332.

Steenwerth, K., Belina, KM (2008) Cover crops enhance soil organic matter, carbon dynamics and microbiological function in a vineyard agroecosystem. Appl Soil Ecol. 40:359-369.

Stein T, Hayen-Schneg N, Fendrik I (1997) Contribution of BNF by Azoarcus sp. BH72 in Sorghum vulgare. Soil Biol Biochem. 29:969-971

Steinmaier N, Ngoliya A (2001) Potential of pasture legumes in low-external-input and sustainable agriculture (LEISA). 1. Results from green manure research in Luapula Province, Zambia. Exp Agric. 37:297-307.

Taulé C, Mareques C, Barlocco C, Hackembruch F, Reis VM, Sicardi M, Battistoni F (2012) The contribution of nitrogen fixation to sugarcane (Saccharum officinarum L.), and the identification and characterization of part of the associated diazotrophic bacterial community. Plant Soil. 356:35-49.

Unkovich M, Herridge D, Peoples M, Cadisch G, Boddey R, Giller K, Alves B, Chalk P (2008) Measuring plantassociated nitrogen fixation in agricultural systems. ACIAR, Canberra.

Urquiaga S, Xavier RP, Morais RF, Batista RB, Schultz N, Leite JM, Maia JS, Barbosa KP, Resende AS, Alves BJR, Boddey RM (2012) Evidence from field nitrogen balance and ${ }^{15} \mathrm{~N}$ natural abundance data for the contribution of biological $\mathrm{N}_{2}$ fixation to Brazilian sugarcane varieties. Plant Soil. 356:5-21.

Videira SS, Silva MCP, Galisa PS, Dias ACF, Nissinen R, Divan VLB, van Elsas JD, Baldani JI, Salles JF (2014) Culture-independent molecular approaches reveal a mostly unknown high diversity of active nitrogen-fixing bacteria associated with Pennisetum purpureum-a bioenergy crop. Plant Soil. 373:737-754.

Wagger MG, Cabrera ML, Ranells NN (1998) Nitrogen and carbon cycling in relation to cover crop residue quality. J Soil Water Conserv. 53:214-218.

Yoon V, Tian G, Vessey JK, Macfie SM, Dangi OP, Kumer AK, Tian L (2016) Colonization efficiency of different sorghum genotypes by Gluconacetobacter diazotrophicus. Plant Soil. 398:243-256.

Zotarelli L, Zatorre NP, Boddey RM, Urquiaga S, Jantalia CP, Franchini JC, Alves BJR (2012) Influence of no-tillage and frequency of a green manure legume in crop rotations for balancing $\mathrm{N}$ outputs and preserving soil organic $\mathrm{C}$ stocks. Field Crop Res. 132:185-195. 